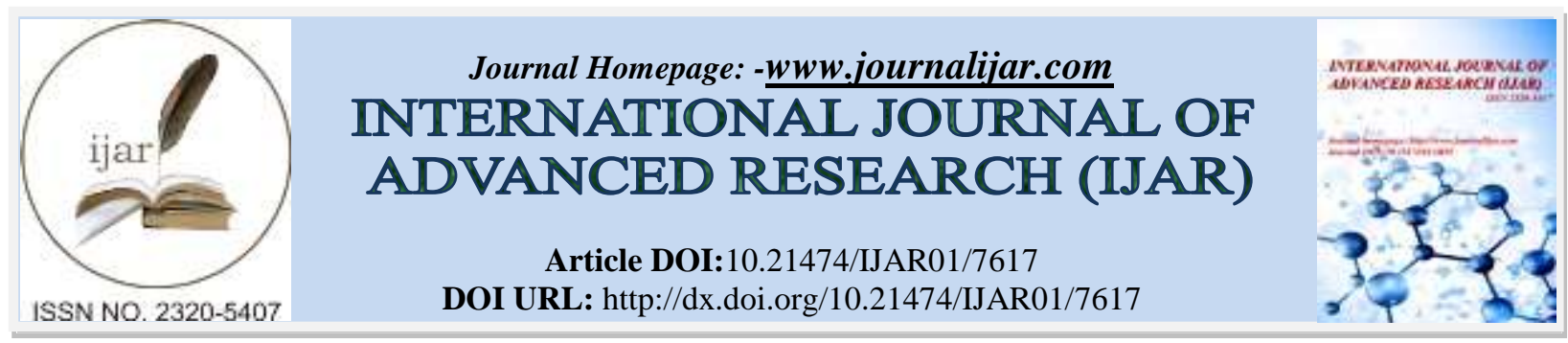

RESEARCH ARTICLE

\title{
IMMUNOSTIMULATORY EFFECTS OF SOME FEED SUPPLEMENTS ON LAYING CHICKEN IMMUNIZED WITH LASOTA VACCINE FOR NEWCASTLE DISEASE.
}

\author{
K. Athis Kumar. \\ Department of Zoology, Sivanthi Aditanar College, Pillayarpuram, Kanyakumari District, Tamilnadu, India-629501.
}

\section{Manuscript Info}

Manuscript History

Received: 22 June 2018

Final Accepted: 24 July 2018

Published: August 2018

\begin{abstract}
This study attempts to demonstrate the use of dietary supplements to enhance the HI titre value, WBC count and lymphocytes of laying hens immunized with LaSota vaccine for Newcastle disease. Different dosages of Lactobacillus acidophyllus, Andrographis paniculata and Sargassum wightii were given to separate groups of similar aged laying hens once in a week and the birds were vaccinated with Lasota vaccine in the ocular route one week before the beginning of the experiment. HI titre, ELISA titre, RBC, WBC, haemoglobin, heterophils, basophils, eosinophils, lymphocytes and monocytes were estimated from the blood samples and IgY in eggs. These dietary supplements had increased the HI titre, ELISA titre, WBC, lymphocytes and monocytes that give immediate protection against NCD and also increased the bird's health by increasing the RBC and haemoglobin and reducing the level of eosinophils. This study recommends the use of $10^{5}$ cells of Lactobacilli or 2 grams of Andrographis powder or 2 grams of Sargassum powder (per kg feed) once in a week for chicken to improve their overall health and immunity of fowls vaccinated with LaSota vaccine for giving complete protection against Newcastle disease.
\end{abstract}

Copy Right, IJAR, 2018,. All rights reserved.

\section{Introduction:-}

Newcastle disease (ND) virus is an avian paramyxovirus that produces pneumoencephalitis in young chickens, turkeys and other domesticated and wild birds (Asplin, 1949). This disease is characterized by respiratory symptoms, neurological symptoms, enteritis, haemorrhagic lesions and often with high mortality (Ballouh et al., 1985), which is generally considered as the most serious poultry disease throughout the world (Herenda and Franco, 1996). The virulent strains of PPMV-1 may cause the mortality up to 100\%.in some farms (Chu and Rizk 1972) and cause dramatic losses in domestic fowls (Ezeokoli et al., 1994) and to the lesser extent in turkeys and pheasants (Ibu et al., 2009).

The circulating strains of NDV are capable of causing both epizootic and enzootic Newcastle diseases in villages and in large scale commercial farms, and they account for up to $100 \%$ mortality in unprotected birds (Ananth et al., 2008). The NCD that has now become endemic in village poultry population recurs every year and inflicts heavy losses (Tadelle and Jobre, 2004). This disease has no cure, but vaccination is the most effective method to control NCD in poultry for reducing the mortality of chicks and adult birds (Spradbrow, 1995; Al-Garib, 2003; Rahman , 2004; Zeleki et al., 2005; Paulillio et al., 2009). Live vaccines prepared with lentogenic strains of NDV are more frequently used for poultry than the vaccines prepared from chemically inactivated strains, mixed with adjuvant 
(Alexander 1997). LaSota is a freeze-dried NDV live vaccine produced on a large scale at a relatively low cost and is in most common use under Indian conditions. This vaccine is easy to administer on a large scale, and it rapidly stimulates humoral, cell-mediated and mucosal immunity in poultry (Chandraseker et al., 1989; Perry and Aitken 1973).

Although poultry in confinements have been continuously vaccinated with LaSota to control NDV, pockets of infection have been reported here and there in vaccinated flocks due to vaccine failure (Roy et al., 2000; Ankele et al., 2014). This vaccine failure may be due to breakdown in the immunity of birds caused by (a) mycotoxins in the feed (Shivachandra et al., 2003), (b) cold/heat stress (El-Lethey, 2003), (c) velogenic strain of NCDV causing the infection (Chaudhry and Chaudhry, 1996), (d) malfunctioning of the bird's immune system (Li et al., 1999; Sharma et al., 2000), and (e) cyclophosphamide drugs used to treat some other viral diseases in poultry (Kim et al., 2004). Breaking the immunity has caused many farmers to lose confidence in the use of vaccines because of doubts about their efficacy.

Immunostimulation of birds is a right choice to enhance the immunity through increased antibody production, increased cellular immune responses, and increased macrophage phagocytic ability, which provides high resistance to the birds against various viral infections (Dugas et al., 1999). The probiotic Lacobacillus acidophyllus has influenced the adaptive immune responses by activating the innate immune system (Maldonado et al., 2006), and enhancing the systemic antibody response to some antigens in chickens (Haghighi et al., 2005). Tollba and Mahmood (2009) have shown that there is a significant increase in counts of erythrocytes (RBC's), leukocytic (WBC's), lymphocytes, eosinophils and basophils, while heterophil count is low when chicken are fed with Lactobacilli at normal temperature $\left(23^{\circ} \mathrm{C}\right)$. Lillehoj and Chung (1992) had reported elevated lymphocytes count in the intestinal propria and blood of chicken receiving Lactobacilli probiotic. Experiments confirm that Andrographis panculata is an immunostimulant to tone up both the innate immunity and acquired immunity in fishes, aquatic animals, birds, cattle and man (Puri et al., 1993). Dietary supplementation of Sargassum wightii has significantly increased the RBC count, WBC's, lymphocytes, basophils, and heterophil count but lowered the eosinophyll count in chickens and pigeons (Athis Kumar, 2017).

In this study, an attempt was made to enhance the HI titre, ELISA titre, WBC count and lymphocytes of the laying hens vaccinated with LaSota vaccine for Newcastle disease by supplementing the feed with different doses of $L$. acidophyllus, A. paniculata and S. wightii.

\section{Materials And Methods:- \\ Experimental Design:-}

Three experiments were conducted in the animal house of Sivanthi Adithanar College, Pillayarpuram during January -June of the year 2018. In each experiment, a total of 75 one-year old Single Comb 'Forsgate' strain White Leghorn layers, belonging to the same hatch and of uniform body size, were randomly grouped into five treatments with 3 four replicates of 5 hens each. In the first experiment, hens in the $1^{\text {st }}$ group were fed only with the conventional feed (control), and those in the those in the $2^{\text {nd }}, 3^{\text {rd }}, 4^{\text {th }}$ and $5^{\text {th }}$ groups were fed with the basal feed as usual and $10^{1}, 10^{3}$, $10^{5}$ and $10^{7}$ cells of Lactobacillus acidophyllus per litre of water once in a week. In the second experiment, hens in the $1^{\text {st }}$ group were fed only with the conventional feed (control), and those in the $2^{\text {nd }}, 3^{\text {rd }}, 4^{\text {th }}$ and $5^{\text {th }}$ groups were fed with the normal feed as usual and $0.5 \mathrm{~g}, 1 \mathrm{~g}, 1.5 \mathrm{~g}$ and $2 \mathrm{~g}$ of Andrographis paniculata powder per Kg of feed once in a week. In the third experiment, hens in the $1^{\text {st }}$ group were fed only with the conventional feed, and those in the $2^{\text {nd }}$, $3^{\text {rd }}, 4^{\text {th }}$ and $5^{\text {th }}$ groups were fed with the normal feed as usual and $0.5 \mathrm{~g}, 1 \mathrm{~g}, 1.5 \mathrm{~g}$ and $2 \mathrm{~g}$ of Sargassum wightii powder per $\mathrm{Kg}$ of feed once in a week. For inducing active immunity against Newcastle Disease, the birds were vaccinated with LaSota vaccine in the ocular route one week prior to the beginning of the experiment. Suitable hygienic conditions and standard managerial practices were followed throughout the experiment. All the hens were fed with the experimental feed and dietary supplements for the duration of 60 days.

\section{Collection of Blood:-}

Blood samples were taken from the birds on the $50^{\text {th }}$ day of experiment. The wing surface at the elbow joint was sterilized by wiping with cotton soaked with surgical spirit and blood sample was taken from the jugular vein through vein puncture using $23 \mathrm{G}$ sterile hypodermic needle of Dispovan Insulin syringe. About $2 \mathrm{ml}$ of blood was taken in from a fowl, as done by Oladele et al. (2008), on the day of experiment and the samples taken from a pair of birds were pooled together as one sample $(4 \mathrm{ml})$ for investigation. Of this, $2 \mathrm{ml}$ is stored in labeled Bijou bottles containing ethylene diamine tetra acetic acid (EDTA) at the concentration of $2 \mathrm{mg} / \mathrm{ml}$ as anti-coagulant for the study 
of haematological parameters and the remaining $2 \mathrm{ml}$ blood was stored in yet other labeled bottle without any anticoagulant for the preparation of serum.

\section{Preparation of Serum:-}

$2 \mathrm{ml}$ of each blood sample was taken in a test tube and its mouth was closed with a cotton plug. The test tube was kept undisturbed at $37^{\circ} \mathrm{C}$ for one hour and then the blood was centrifuged at $2000 \mathrm{~g}$ for 10 minutes. Serum in the fluid was carefully poured into a screw-cap tube and stored at $-20^{\circ} \mathrm{C}$ for the further study.

HI titer assay for NDV

To confirm the infections with PPMV-1, sera of all the birds were subjected to HA and HI titer assay according to the standard methods described by Hanson (1975). The test was carried out by running two fold dilutions of equal volumes $(25 \mu \mathrm{l})$ of Phosphate Buffered Saline (PBS) and test serum in U-bottomed micro titer plates. 4 Hemagglutination units (HAU) of the viral antigen of LaSota strain obtained from CIRAD, France was added to each well and the plates were left at room temperature for a minimum of $30 \mathrm{~min} .25 \mu \mathrm{l}$ of $1 \%$ (v/v) chicken RBCs collected from pathogen-free chickens older than 3 weeks and serologically negative to NCD antibody was added to each well. After gentle mixing, the plates were allowed to settle for about 40 minutes at room temperature. The HI titer was read from the highest dilution of serum causing complete inhibition of $4 \mathrm{HAU}$ of antigen. Those wells that showed sedimentation of RBC as the control wells were considered as inhibition. A titer greater than or equal to 1:8 was taken as positive.

\section{Elisa Test:-}

The serum samples were also utilized for estimation of ELISA titre for Newcastle Disease, as per the procedure of Office International des Epizooties (2000).

Haematological Parameters

Hematological parameters like red blood cells (RBC) count, haemoglobin (Hb) concentration, WBC and differential count for heterophilis, basophils, eosinophils, monocytes and lymphocytes were determined using standard techniques described by Rehman et al. (2003).

Immunoglobulin-Y Estimation

On the $50^{\text {th }}$ day of experiment, one egg was collected from each replicate. Thus, a total of 24 eggs were utilized for the estimation of IgY level in the yolk, according to the procedure described by Polson (1980).

Statistical analysis

All the data obtained from this experiment were subjected to one-way ANOVA, using SPSS (1997) computer software. The significant differences among the means values were analyzed with the Duncan multiple range test (Duncan, 1955).

\section{Results and Discussion:-}

Dietary supplementation of Lactobacilli at weekly interval significantly ( $p>0.05)$ increased the RBC, WBC, haemoglobin, basophils, lymphocytes and monocytes and decreased the heterophils and eosinophils in the blood compared to the blood of control (Table 1). Dietary treatments with Andrographis powder had significantly ( $>0.05)$ increased the WBC, basophils, heterophils, lymphocytes and monocytes, and decreased the RBC, haemoglobin and eosinophils in the blood compared to the control (Table 2). Table 3 clearly shows that Sargassum powder significantly ( $>0.05$ ) increased the RBC, WBC, haemoglobin, heterophils, basophils, lymphocytes and monocytes and decreased the eosinophils in the blood compared to the blood of control. The maximum immunostimulating effect was observed at $10^{7}$ cells of Lactobacilli, $2 \mathrm{~g}$ Andrographis powder and $2 \mathrm{~g}$ Sargassum powder per kg of feed, of which Andrographis had the maximum modulating effect followed by Sargassum and Lactobacilli.

Bone marrow which is the site of haematopoiesis contains all the cytokines required for the proliferation and differentiation of haemopoetic cells via positive and negative regulation of various cytokines, cytokine receptors and other regulatory peptides (Bloom, 1938). A combination of more than one cytokine in small concentrations may up regulate or down regulate the different lineages of haemopoetic precursors to produce characteristic cell types (Hittler et al., 1992; Fan et al., 2006). Bagby and Heinrich (2000) clearly reviewed that in humans IL-3, IL-9, IL-11 and GM-CSF are required for the production of erythrocytes from myeloid progenitors, IL-3, GM-CSF, M-CSF and G-CSF are necessary for the production of neutrophils, IL-3, IL-5 and GM-CSF are inevitable for the production of 
eosinophils, IL-3 and TGF promote the production of basophils, IL-1, IL-6,TNF and GS-CSF are required for the production of monocytes, and IL-2, IL-7, IL-4, IL-10, IL-12, IL-13, IL-14 and IL-16 required for the formation and proliferation of lymphocytes from lymphocytes progenitors. Further, IL-1 and TNF act synergistically to stimulate the myeloid progenitors to produce red blood cells (Kittler et al., 1992). Therefore, Lactobacilli might have up regulated the expression of IL-1, IL-2, IL-3, IL-10, IL-11, IL-12, IL-13, IL-14, IL-15, IL -16, GM-CSF, TGF and TNF while down regulated the expression of IL-5, M-CSF and G-CSF in chicken; Andrographis powder might have up regulated the expression of IL-1, IL-2, IL-3, IL-10, IL-12, IL-13, IL-14, IL-15, IL -16, TGF and TNF while down regulated the expression of IL-5, IL-9, IL-11 and GM-CSF; and Sargassum powder might have up regulated the expression of IL-1, IL-2, IL-3, IL-5, IL-10, IL-11, IL-12, IL-13, IL-14, IL-15, IL -16, GM-CSF, TGF, TNF, M-CSF and G-CSF in pigeons. However, it needs further confirmation by RT-PCR with known probes. In the same line of invention, Choi et al (1999) had already proved that Lactobacilli up regulate the expression of IFN- $\gamma$, IL-1, IL-12, IL10 and IGF- $\beta$ in domestic fowls.

Table 1:-Effects of different dosages of Lactobacillus acidophyllus on the RBC, WBC, Hb and differential cell count of WBC in chcken vaccinated with LaSota. $(n=15)$.

\begin{tabular}{|c|c|c|c|c|c|}
\hline Blood component & Control & $10^{1}$ Lactobacilli & $10^{3}$ Lactobacilli & $10^{5}$ Lactobacilli & $10^{7}$ Lactobacilli \\
\hline $\mathrm{RBC}\left(\times 10^{6} / \mathrm{mm}^{3}\right)$ & $2.42 \pm 0.17^{\mathrm{a}}$ & $2.51 \pm 0.21^{b}$ & $2.62 \pm 0.17^{b}$ & $2.74 \pm 0.26^{b}$ & $2.83 \pm 0.23^{b}$ \\
\hline $\mathrm{WBC}\left(\times 10^{3} / \mathrm{mm}^{3}\right)$ & $25.22 \pm 2.23^{\mathrm{a}}$ & $26.52 \pm 2.27^{\mathrm{a}}$ & $28.34 \pm 1.84^{\mathrm{a}}$ & $31.33 \pm 2.28^{b}$ & $33.47 \pm 2.17^{b}$ \\
\hline Haemoglobin $(\mathrm{g} \%)$ & $9.22 \pm 0.12^{\mathrm{a}}$ & $9.26 \pm 0.31^{\mathrm{b}}$ & $9.43 \pm 0.32^{\mathrm{a}}$ & $9.53 \pm 0.27^{\mathrm{a}}$ & $9.68 \pm 0.21$ \\
\hline Heterophils (\%) & $19.73 \pm 0.32^{a}$ & $19.22 \pm 0.42^{b}$ & $18.83 \pm 0.31^{b}$ & $17.11 \pm 0.26^{b}$ & $16.70 \pm 0.28^{b}$ \\
\hline Basophils (\%) & $1.72 \pm 0.09^{\mathrm{a}}$ & $1.78 \pm 0.06^{\mathrm{b}}$ & $1.83 \pm 0.07^{\mathrm{a}}$ & $1.88 \pm 0.08$ & $1.96 \pm 0.06^{\mathrm{b}}$ \\
\hline Eosinophils (\%) & $2.20 \pm 0.21^{\mathrm{a}}$ & $2.02 \pm 0.13^{b}$ & $1.86 \pm 0.23^{b}$ & $1.72 \pm 0.21^{\mathrm{b}}$ & $1.61 \pm 0.11^{\mathrm{b}}$ \\
\hline Lymphocytes (\%) & $66.42 \pm 8.32^{\mathrm{a}}$ & $68.33 \pm 9.14^{b}$ & $70.37 \pm 8.82^{b}$ & $71.68 \pm 7.64^{\mathrm{a}}$ & $73.39 \pm 6.37^{\mathrm{a}}$ \\
\hline Monocytes (\%) & $9.80 \pm 0.16^{\mathrm{a}}$ & $9.88 \pm 0.11^{\mathrm{b}}$ & $10.12 \pm 0.20^{b}$ & $10.41 \pm 0.18^{b}$ & $10.51 \pm 0.19^{b}$ \\
\hline
\end{tabular}

$*^{\mathrm{a}}$ is the significance $\mathrm{p}<0.05 ;^{\mathrm{b}}$ is the significance value $\mathrm{p}>0.05$.

Table 2:-Effects of different dosages of Andrographis paniculata on the RBC, WBC, Hb and differential cell count of WBC in chicken vaccinated with LaSota. $(n=15)$.

\begin{tabular}{|c|c|c|c|c|c|}
\hline Blood component & Control & $0.5 \mathrm{~g}$ powder & $1.0 \mathrm{~g}$ powder & $1.5 \mathrm{~g}$ powder & 2.0g powder \\
\hline $\mathrm{RBC}\left(\times 10^{6} / \mathrm{mm}^{3}\right)$ & $2.42 \pm 0.17^{\mathrm{a}}$ & $2.52 \pm 0.15^{\mathrm{a}}$ & $2.73 \pm 0.17^{\mathrm{a}}$ & $2.91 \pm 0.14^{b}$ & $3.16 \pm 0.13^{b}$ \\
\hline WBC $\left(\times 10^{3} / \mathrm{mm}^{3}\right)$ & $25.22 \pm 2.23^{\mathrm{a}}$ & $27.11 \pm 2.29^{b}$ & $28.44 \pm 1.34^{b}$ & $30.51 \pm 2.23^{\mathrm{a}}$ & $34.88 \pm 2.12^{b}$ \\
\hline Haemoglobin $(\mathrm{g} \%)$ & $9.21 \pm 0.12^{\mathrm{a}}$ & $9.06 \pm 0.22^{\mathrm{a}}$ & $8.84 \pm 0.12^{\mathrm{a}}$ & $8.75 \pm 0.20^{b}$ & $8.66 \pm 0.19^{b}$ \\
\hline Heterophils (\%) & $19.73 \pm 0.31^{\mathrm{a}}$ & $19.78 \pm 0.43^{\mathrm{a}}$ & $19.84 \pm 0.21^{\mathrm{a}}$ & $19.89 \pm 0.24$ & $19.97 \pm 0.22^{b}$ \\
\hline Basophils (\%) & $1.72 \pm 0.09^{\mathrm{a}}$ & $1.74 \pm 0.05^{\mathrm{a}}$ & $1.79 \pm 0.04^{\mathrm{b}}$ & $1.83 \pm 0.05^{b}$ & $1.88 \pm 0.04^{b}$ \\
\hline Eosinophils (\%) & $2.20 \pm 0.21^{\mathrm{a}}$ & $2.01 \pm 0.16^{\mathrm{a}}$ & $1.74 \pm 0.21^{\mathrm{b}}$ & $1.64 \pm 0.20^{\mathrm{a}}$ & $1.59 \pm 0.12^{b}$ \\
\hline Lymphocytes (\%) & $66.42 \pm 8.32^{\mathrm{a}}$ & $68.76 \pm 9.27^{\mathrm{a}}$ & $71.87 \pm 8.33^{b}$ & $72.68 \pm 8.37^{b}$ & $74.49 \pm 8.48^{b}$ \\
\hline Monocytes (\%) & $9.80 \pm 0.15^{\mathrm{a}}$ & $9.84 \pm 0.12^{\mathrm{a}}$ & $8.90 \pm 0.21$ & $8.91 \pm 0.19^{a}$ & $8.95 \pm 0.19^{b}$ \\
\hline
\end{tabular}

$*^{\mathrm{a}}$ is the significance $\mathrm{p}<0.05 ;^{\mathrm{b}}$ is the significance value $\mathrm{p}>0.05$.

Table 3:-Effects of different dosages of Sargassum wightti on the RBC, WBC, Hb and differential cell count of WBC in chcken vaccinated with LaSota. $(n=15)$.

\begin{tabular}{|l|l|l|l|l|l|}
\hline Blood component & Control & $0.5 \mathrm{~g}$ powder & 1.0 g powder & $1.5 \mathrm{~g}$ powder & $2.0 \mathrm{~g}$ powder \\
\hline RBC $\left(\times 10^{6} / \mathrm{mm}^{3}\right)$ & $2.42 \pm 0.17^{\mathrm{a}}$ & $3.21 \pm 0.19^{\mathrm{a}}$ & $3.46 \pm 0.12^{\mathrm{a}}$ & $3.71 \pm 0.36^{\mathrm{b}}$ & $3.83 \pm 0.34^{\mathrm{b}}$ \\
WBC $\left(\times 10^{3} / \mathrm{mm}^{3}\right)$ & $25.22 \pm 2.23^{\mathrm{a}}$ & $26.52 \pm 2.27$ & $28.34 \pm 1.84^{\mathrm{a}}$ & $31.33 \pm 2.28^{\mathrm{a}}$ & $33.47 \pm 2.17^{\mathrm{b}}$ \\
Haemoglobin $(\mathrm{g} \%)$ & $9.22 \pm 0.12^{\mathrm{a}}$ & $9.46 \pm 0.11^{\mathrm{b}}$ & $9.63 \pm 0.22^{\mathrm{a}}$ & $9.93 \pm 0.26^{\mathrm{a}}$ & $10.24 \pm 0.21^{\mathrm{b}}$ \\
Heterophils (\%) & $19.73 \pm 0.32^{\mathrm{a}}$ & $19.89 \pm 0.32^{\mathrm{a}}$ & $19.96 \pm 0.22^{\mathrm{b}}$ & $20.11 \pm 0.19^{\mathrm{a}}$ & $20.32 \pm 0.18^{\mathrm{b}}$ \\
Basophils $(\%)$ & $1.72 \pm 0.09^{\mathrm{a}}$ & $1.80 \pm 0.05^{\mathrm{b}}$ & $1.87 \pm 0.03^{\mathrm{a}}$ & $1.91 \pm 0.06^{\mathrm{b}}$ & $1.96 \pm 0.04^{\mathrm{b}}$ \\
Eosinophils (\%) & $2.20 \pm 0.21^{\mathrm{a}}$ & $2.10 \pm 0.33^{\mathrm{a}}$ & $1.76 \pm 0.19^{\mathrm{a}}$ & $1.70 \pm 0.23^{\mathrm{a}}$ & $1.60 \pm 0.11^{\mathrm{b}}$ \\
Lymphocytes (\%) & $66.42 \pm 8.32^{\mathrm{a}}$ & $68.65 \pm 9.27^{\mathrm{a}}$ & $71.31 \pm 8.98^{\mathrm{b}}$ & $72.28 \pm 6.71^{\mathrm{b}}$ & $73.97 \pm 6.29^{\mathrm{b}}$ \\
Monocytes $(\%)$ & $9.80 \pm 0.15^{\mathrm{a}}$ & $9.82 \pm 0.13^{\mathrm{a}}$ & $8.85 \pm 0.21^{\mathrm{a}}$ & $8.89 \pm 0.17^{\mathrm{a}}$ & $8.92 \pm 0.18^{\mathrm{b}}$ \\
\hline
\end{tabular}

$*^{\mathrm{a}}$ is the significance $\mathrm{p}<0.05 ;{ }^{\mathrm{b}}$ is the significance value $\mathrm{p}>0.05$.

Innate immune system has been viewed as a scavenger system that fights against the invading pathogens immediately after they enter the body either by means of phagocytosis or by lysis of pathogens (Juul-Madsen, 2008). Phagocytosis is associated with heterophils, basophils and monocytes while lysis is associated with lysozymes and other molecular cascade systems. Heterophils have phagocytic capability due to oxidative burst (Montali, 1988). 
The activation of heterophils by pathogens or by cytokines induces the expression of various pro-inflammatory cytokines such as IL-1, IL-6 and IL-8 (Kogut et al., 2005). Monocytes derived macrophages and basophils are induced to engulf the pathogenic microbes by TLR7/8 proteins which are often stimulated by feed supplements (Philbin et al., 2005). Expression of defensins has been reported with heterophils and macrophages to destroy pathogens (Zhao et al., 2001; Sugiarto and Yu, 2004), which is yet other innate protection of the organism. In laying hens, increase in heterophil- lymphocyte ratio provides much innate immunity to the fowl (Campo et al., 2005). All the chosen feed supplements have increased the heterophil: lymphocyte ratio in chicken, which indicates that these feed supplements have enhanced the innate immunity of chicken. Lymphocytes are essential for generating immune responses and for retaining the memory of previous exposure to an antigen (Burnet, 1971) and they take part in the innate immunity as well as in the adaptive immunity to fight against the pathogens (Silverstein, 2001). Results of this study agree with the above said findings and reveal that these feed supplements have modulated the expression of various cells involving in the innate immunity of chicken.

Table 4:-Effects of different dosages of L. acidophyllus on the HI titre, ELISA titre and IgY values in chicken vaccinated with LaSota. $(n=15)$.

\begin{tabular}{|l|l|l|l|l|l|}
\hline Blood component & Control & $10^{1}$ Lactobacilli & $10^{3}$ Lactobacilli & $10^{5}$ Lactobacilli & $10^{7}$ Lactobacilli \\
\hline HI titre $\left(\log _{2}\right)$ & $4.4 \pm 0.21^{\mathrm{a}}$ & $4.6 \pm 0.33^{\mathrm{a}}$ & $5.20 \pm 0.26^{\mathrm{a}}$ & $5.74 \pm 0.32^{\mathrm{a}}$ & $6.44 \pm 0.17^{\mathrm{b}}$ \\
ELISA $\left(\log _{2}\right)$ & $2.33 \pm 0.06^{\mathrm{a}}$ & $2.42 \pm 0.03^{\mathrm{b}}$ & $2.71 \pm 0.05^{\mathrm{b}}$ & $2.82 \pm 0.04^{\mathrm{b}}$ & $3.37 \pm 0.06^{\mathrm{b}}$ \\
IgY (mg/g yolk) & $14.78 \pm 0.04^{\mathrm{a}}$ & $15.73 \pm 0.03^{\mathrm{a}}$ & $18.24 \pm 0.05^{\mathrm{b}}$ & $18.63 \pm 0.05^{\mathrm{b}}$ & $19.32 \pm 0.06^{\mathrm{b}}$ \\
\hline
\end{tabular}

$*^{\mathrm{a}}$ is the significance $\mathrm{p}<0.05 ;^{\mathrm{b}}$ is the significance value $\mathrm{p}>0.05$.

Table 5:-Effects of different dosages of A. paniculata on the HI titre, ELISA titre and IgY values in chicken vaccinated with LaSota. $(\mathrm{n}=15)$.

\begin{tabular}{|l|l|l|l|l|l|}
\hline Blood component & Control & $0.5 \mathrm{~g}$ powder & 1.0 g powder & $1.5 \mathrm{~g}$ powder & $2.0 \mathrm{~g}$ powder \\
\hline HI titre $\left(\log _{2}\right)$ & $4.24 \pm 0.30^{\mathrm{a}}$ & $4.5 \pm 0.23^{\mathrm{b}}$ & $5.31 \pm 0.24^{\mathrm{b}}$ & $5.97 \pm 0.33^{\mathrm{a}}$ & $6.87 \pm 0.26^{\mathrm{b}}$ \\
ELISA $\left(\log _{2}\right)$ & $2.34 \pm 0.05^{\mathrm{a}}$ & $2.34 \pm 0.04^{\mathrm{a}}$ & $2.88 \pm 0.06^{\mathrm{a}}$ & $2.98 \pm 0.05^{\mathrm{b}}$ & $3.63 \pm 0.05^{\mathrm{b}}$ \\
IgY $(\mathrm{mg} / \mathrm{g}$ yolk) & $14.72 \pm 0.06^{\mathrm{a}}$ & $16.23 \pm 0.04^{\mathrm{a}}$ & $18.64 \pm 0.04^{\mathrm{b}}$ & $19.29 \pm 0.06^{\mathrm{a}}$ & $19.30 \pm 0.06^{\mathrm{b}}$ \\
\hline
\end{tabular}

$*^{\mathrm{a}}$ is the significance $\mathrm{p}<0.05 ;^{\mathrm{b}}$ is the significance value $\mathrm{p}>0.05$.

Table 6:-Effects of different dosages of S. wightii on the HI titre, ELISA titre and IgY values in chicken vaccinated with LaSota. $(\mathrm{n}=15)$.

\begin{tabular}{|l|l|l|l|l|l|}
\hline Blood component & Control & $0.5 \mathrm{~g}$ powder & $1.0 \mathrm{~g}$ powder & $1.5 \mathrm{~g}$ powder & $2.0 \mathrm{~g}$ powder \\
\hline HI titre $\left(\log _{2}\right)$ & $4.24 \pm 0.22^{\mathrm{a}}$ & $4.4 \pm 0.31^{\mathrm{b}}$ & $5.26 \pm 0.23^{\mathrm{a}}$ & $5.81 \pm 0.36^{\mathrm{b}}$ & $6.74 \pm 0.21^{\mathrm{b}}$ \\
ELISA $\left(\log _{2}\right)$ & $2.33 \pm 0.03^{\mathrm{a}}$ & $2.30 \pm 0.04^{\mathrm{a}}$ & $2.76 \pm 0.04^{\mathrm{b}}$ & $2.86 \pm 0.04^{\mathrm{b}}$ & $3.44 \pm 0.05^{\mathrm{b}}$ \\
IgY (mg/g yolk) & $14.77 \pm 0.03^{\mathrm{a}}$ & $15.87 \pm 0.05^{\mathrm{a}}$ & $18.54 \pm 0.03^{\mathrm{b}}$ & $19.33 \pm 0.04^{\mathrm{b}}$ & $19.48 \pm 0.05^{\mathrm{b}}$ \\
\hline
\end{tabular}

$*^{\mathrm{a}}$ is the significance $\mathrm{p}<0.05 ;{ }^{\mathrm{b}}$ is the significance value $\mathrm{p}>0.05$.

The HI test is the most widely used serological method for measuring anti-NDV antibody levels in poultry sera and is still a standard laboratory method for diagnosis of NDV (Jestin, 1989). In poultry vaccinated with LaSota vaccine, the HI titre was $4.24 \log 2$, which was further increased to $4.6-6.4 \log 2$ by Lactobacilli (Table 4), to 4.5 $6.87 \log 2$ by Andrographis powder (Table 5), and to $4.4-6.74 \log 2$ by Sargassum powder (Table 6). The HI titre value increased with increasing dosages of these supplements, reaching the peak at the highest dosage used in the experiment. Allen et al (1974) have evaluated that HI titre value higher than $5.2 \log 2$ can give adequate protection against NCDV infections. All these feed supplements had raised the HI titre above $5.2 \log 2$, and hence they are enough for providing adequate protection to birds against the Newcastle disease. This result is in the same line of investigation made by Ojiezeh et al. (2013), who highlighted the relevance of vaccination in disease prevention, control and management of NDV disease. It further confirms that Angrographis powder is the most potent in stimulating the immune system to produce anti-NCDV antibodies in laying hens.

The mean ELISA titres of poultry fed with Lactobacilli, Andrographis and Sargassum powder were significantly ( $p>0.05)$ different from the control. ELISA titres represent the stimulation of sero conversion of NCDV due to the modulating effects of these feed supplements. Such seroconversion increased with increasing dosages of the feed supplements to the usual poultry feed and the highest effect was observed at $10^{7}$ cells dosage of Lactobacilli, $2 \mathrm{~g}$ Andrographis powder and $2 \mathrm{~g}$ Sargassum powder (per $\mathrm{Kg}$ of feed). The protection rate did not differ significantly at 
different doses of supplements, but without doubt there was rise in the humoral immunity as reported by De Roose (2000), Sharif (2007) and Zhang et al 2007).

IgY level in the eggs of control was $14.72 \mathrm{mg} / \mathrm{g}$, and it was increased up to $19.32 \mathrm{mg} / \mathrm{g}$ by L. acidophilus (Table 4), up to $19.30 \mathrm{mg} / \mathrm{g}$ by Andrographis powder (Table 5), and up to $19.48 \mathrm{mg} / \mathrm{g}$ by Sargassum powder (Table 6). Andrographis powder had slightly reduced the IgY level in the egg while Lactobacillus and Sargassum powder increased the IgY content of eggs, which represents their immune modulating activity as concluded in the by studies of Kirubakaran (2003) and Narahari et al. (2004), who observed that dietary supplements had induced the eggs to accumulate higher level of $\mathrm{IgY}$.

\section{Conclusions:-}

This study concludes that LaSota vaccine is a safe live vaccine that gives protection to chicken against NCDV, but the amount of anti-NCDV antibodies produced in most circumstances is inadequate to give complete protection against Newcastle disease because of vaccine failure. Feed supplements used in this study stimulate humoral immune response of vaccinated chicken to produce some additional amount of anti-NCDV antibodies for HI titres above $5.2 \log 2$ giving complete protection against the NCD. In the meantime, they enhance the production of WBC, lymphocytes and monocytes, which give innate immunity to the chicken to fight against the invasion of NCDV and some other infections like Avian Influenza (AI) virus. Rise in the level of RBC count and haemoglobin and reduction in the eosinophils count indicate improvement in the general health of chicken. This study therefore recommends the use of $10^{5}$ cells of Lactobacilli or 2 grams of Andrographis powder or 2 grams of Sargassum powder (per kg feed) once in a week for chicken to improve their overall health and immunity of fowls vaccinated with LaSota vaccine, which would definitely give complete protection against Newcastle disease.

\section{References:-}

1. Alders, R and P. Spradbrow. 2001. Controlling of Newcastle disease in village chickens. A Field Manual. Australian Center of International Agricultural Research (ACIAR), 2001.

2. Alexander, D.J.1997. Newcastle Disease and Other Paramyxoviridae Infections.In: Diseases Of Poultry, 10th Ed., BW. Calnek, HJ. Barnes, CW. Beard, LR. Mcdougald, and YM. Saif (eds). Iowa State University Press, AMES, USA. 541- 569.

3. Al-Garib, S.2003. Newcastle disease virus: immune reactivity and pathogenesis, PhD thesis, Utrecht University, Faculty of Veterinary Medicine, The Netherlands.

4. Allan, W.H., and R.E. Gough.1974. A Standard Haemagglutination Inhibition Test for Newcastle Disease. A Comparison of Macro and Micro Methods. Vet.Record, 95: 120-123.

5. Ananth, R., J.J. Kirubaharam, M.L.M. Priyadarshini and A. Albert. 2008. Isolation of NDVes of high virulence in unvaccinated healthy village chickens in south India. Intl J Poult Sci. , 2008,7(4),368-373.

6. Asplin, F.D. 1949. Observations on the viability of Newcastle disease. Veterinary Record 61(13):159-160.

7. Athis Kumar, K. 2017. Growth, Reproduction and Immunomodulation of Lahore Pigeons in Response to Dietary Supplementation of Lactobacillus acidophilus, Andrographis paniculata and Sargassum wightii, PhD Thesis Submitted to Manonmaniam Sundaranar University, Tirunelveli, pp. 290p.

8. Bagby, G.C. and M.C. Heinrich. 2000. Growth Factors, Cytokines, and the Control of Hematopoiesis. In: Hoffman: Hematology: Basic Principles and Practice, 3rd ed., 2000 Churchill Livingstone, Inc.

9. Ballouh, A., E. M. Abu-Elzein and A. K. Elmubarak, 1985. Outbreak of the pigeon paramyxovirus serotype -1 in the Sudan. Vet. Rec., 116: 375.

10. Bloom, W. 1938. Lymphocytes and monocytes. Theories of hematopoiesis. In Downey's Handbook of Hematology. 334-35. P. B. Hoeber, Inc. New York.

11. Burnet, M. 1971. Cellular Immunology. Cambridge University Press, Cambridge.

12. Campo, J.L., M.G. Gil, S.G. Davila, and I. Munoz, 2005. Influence of perches and footpad dermatitis on tonic immobility and heterophil to lymphocyte ratio of chickens. Poult. Sci. 84, 1004-1009.

13. Chandraseker, S., R.A. Vankatesan, V.D. Padmanaban, and P.R. Masslliamony. 1989. Nature of Protective Immunity Response in Chicken against Ranikhet Disease. Indian Vet.Jour.,66: 801-806.

14. Chaudhry, K. M. and R.A. Chaudhry. 1999. Causes of vaccine failure. Vet Int. 1996;12: 13-15.

15. Choi, K. D., H. S. Lillehoj, and D. S. Zalenga. 1999. Changes in local IFN- $\gamma$ and TGF- $\beta 4$ mRNA expression and intraepithelial lymphocytes following Eimeria acervulina infection. Vet. Immunol. Immunopathol. 71:263275.

16. Chu, H.P. and J. Rizk.1972. Newcastle Disease, a World Poultry Problem. World Animal Review,2: 33-43. 
17. De Roos, N. M. and M.B. Katan. 2000. Effects of probiotic bacteria on diarrhea lipid metabolism and carcinogenesis: A review of papers published between 1988 and 1998. Am. J. Clin. Nutr. 2000 71:405-411.

18. Dugas, B., A. Mercenier, I. Lenoir-Wijnkoop, C. Arnaud, N. Dugas and E. Postaire. 1999. Immunity and probiotics. Immunol Today. 1999;20:387- 390.

19. Duncan, D. B. 1955.Multiple range and multiple F-test. Biometrics 11: 1-42.

20. El-Lethey, H., B. Huber-Eicher and T.W. Jungi. 2003. Exploration of stressinduced immunosuppression in chickens reveals both stress- resistant and stress-susceptible antigen responses. Vet Immunol Immunopathol. 2003;95:91-101.

21. Ezeokoli, C.D., J.U. Umoh, A.A. Adesuyin and P. Abdu.1994. Prevalence of Newcastle disease virus antibodies in local and exotic chicken under different management systems in Nigeria. Bulletin of Animal Health and Production in Africa,32: 253-257.

22. Fan H., D.L. Williams, B. Zingarelli, K.F. Breuel, G. Teti, G.E. Tempel, K. Spicher, G. Boulay, L. Birnbaumer, P.V. Halushka and J.A. Cook. 2006. Differential regulation of lipopolysaccharide and Gram-positive bacteria induced cytokine and chemokine production in splenocytes by Galphai proteins. Biochim. Biophys. Acta. 1763: 1051-1058.

23. Gordon, R. F and F,T.W. Jordan FTW. 1982. Paramyxoviridae. Poultry diseases. 2 nd ed. London.,1982, $97-113$.

24. Haghighi, H. R., J. Gong, C.L. Gyles, M.A. Hayes, B. Sanei, P. Parvizi, H. Gisavi, J. Chambers and S.H. Sharif. 2005. Modulation of antibody-mediated immune response by probiotics in chickens. Clin. Diagn. Lab. Immunol. 12:1387-1392. by the gut microflora and probiotics. Kluwer Academic, Dordrecht, the Netherlands. 2005; PP: 176-192.

25. Hanson, L.W. 1975. Newcastle disease, In: Isolation and Identification of avian pathogens, Hitchner S.B., Ed., New York,Amold Printing Corporation, pp. 160-173.

26. Herenda, D.C. and D.A. Franco. 1996. Newcastle disease (ND), Viscerotropic Velogenic Newcastle disease (VVND), Neurotropic Velogenic Newcastle disease (NVND), Pneumoencephalitis, Fowl pest. Poultry diseases and Meat hygiene. Iowa state university, Ames, USA. ,1996, 241-243.

27. Ibu, O.J., J.A.O. Okoye, E.P.Adulugba, K.F. Chan, S.V.O. Shoyinka, E. Salihu, A.A. Chukwuedo and S.S. Baba. 2009. Prevalence of Newcastle diseases viruses in wild and captive birds in central Nigeria. Intl J Poult. Sci. ,2009, 8(6), 574-578.

28. Jestin, V., M. Cherbonnel, R.L. Hospitalier and G. Bennejean. 1989. An ELISA blocking test using a peroxidase-labelled anti-HN monoclonal antibody for the specific titration of antibodies to avian Paramyxovirus type 1 (PMV1). Arch Virol. ,1989,105,199-209.

29. Juul-Madsen, H. R., B. Viertlboeck, A. L. Smith and T. W.F. Gobel, 2008. Avian Innate Immune Response, In: Davison, F., B. Kasper and K.A.Schat (Eds) AvianImmunology, Academic Press, Elsivere, London.

30. Kim, Y., T.P. Brown and M.J. Pantin-Jackwood. 2004. The effects of cyclophosphamide treatment on the pathogenesis of subgroup $\mathrm{J}$ avian leukosis virus (ALV-J) infection in broiler chickens with Marek's disease virus exposure. JVet Sci. 2004;5:49-58.

31. Kirubaharan, J. 1996. Preparation and standardisation of inactivated vaccine against Newcastle Disease. PhD, Thesis. Tamilnadu Veterinary and Animal Sciences University, Chennai, India.

32. Kirubakaran, A. 2003. Influence of different diets on egg composition and quality. MVSc, Thesis, Tamil Nadu Veterinary and Animal Sciences University, Chennai, India.

33. Kittler, E.L., H. McGrath and D. Temeles. 1992. Biologic significance of constitutive and subliminal growth factor production by bone marrow stroma. Blood 79:3168, 1992.

34. Kogut, M.H., L. Rothwell, and P. Kaiser, 2005. IFN-gamma priming of chicken heterophils up regulates the expression of proinflammatory and Th1 cytokine mRNA following receptor-mediated phagocytosis of Salmonella enterica serovar Enteritidis. J. Interferon Cytokine Res. 25, 73-81.

35. Li, Y.C., D.R. Ledoux, A.J. Bermudez, K.L. Fritsche and G.E. Rottinghaus. 1999. Effects of fumonisin B1 on selected immune responses in broiler chicks. Poult Sci. 1999;78:1275-1282.

36. Lillehoj, H.S. and K.S. Chung. 1992. Postnatal development of T-lymphocyte subpopulations in the intestinal intraepithelium and lamina propria in chickens. Veterinary Immunology and Immunopathology, 31:347- 360.

37. Maassen, C. B., J. D. Laman, W. J. Boersma and E. Claassen. 2001. Modulation of cytokine expression by lactobacilli and its possible therapeutic use. In R. Fuller and G. Perdigon (ed.), Probiotics, 2001; 3: immunomodulation.

38. Maldonado Galdeano C and G.Perdigo. 2006. The probiotic bacterium Lactobacillus casei induces activation of the gut mucosal immune system through innate immunity. Clin. vaccine Immunol. 2006; 13: 219-226. 
39. Montali, R.J. 1988. Comparative pathology of inflammation in the higher vertebrates (reptiles, birds and mammals). J. Comp. Pahol. 99, 1-26.

40. Narahari, D., A. Kirubakaran and R. Kumararaj. 2004. Influence of herbal enriched functional eggs consumption on serum lipid profile in humans. In: XXII World's Poultry Congress, Istanbul, Turkey: p: 844.

41. Nemcová, R. 1997. Criteria for selection of lactobacilli for probiotic use. Vet. Med. 1997; 42: 19-27.

42. OIE, 2000. Office International des Epizooties Manual. Manual of standards for Diagnostic tests and Vaccines. 4 th edn, France.

43. Ojiezeh, T.I., E.A. Ophori, N.O. Eghafona, G.O.N. Echiowun, T.M. Joannis and R.Y. Akele. 2013. Pilot Study on Effects of Vaccination on Immunity of Broiler Chickens. Journal of Biology, Agriculture and Healthcare, 3 (13): 1-4.

44. Oladele, S.B., M. Morou, S.j. Sambo and O. J. Ibu (2008). Comparative studies of packed cell volume, haemoglobin, total protein, haemagglutination inhibition antibodies and rectal temperature of pigeon (Colambo livia) administered Newcastle disease virus through different routs, International Journal of Poultry Science, 7(9): 898-902.

45. Parry, S.H. and I.D. Aitken. 1973. Immunoglobulin a in the Respiratory Tract of the Chicken Following Exposure Newcastle Disease Virus. Veteri. Record,93: 258-260.

46. Paulillio, A.C., V. Franzo, E.M.S. Schmidt and L.D. Junio. 2009. Response to experimental vaccination in domestic ducks; Clinical and Immunological parameters. Intl J Poult Sci. , 2009,8(10),963-965.

47. Philbin, V.J., M. Iqbal, Y. Boyd, M. J. Goodchild, R.K. Beal, N. Bumstead, J. Young, and A.L. Smith, 2005. Identification and characterization of a functional, alternatively spliced Toll-like receptor 7 (TLR7) and genomic disruption of TLR8 in chickens. Immunology 114, 507-521.

48. Polson, A., W.M. Von and R.M. Van, 1980. Isolation of viral IgY antibodies from yolks of Immunized hens. Immunological Communication, 9: 475-493.

49. Puri, A., R. Saxena, R.P. Saxena, K.C. Saxena, V. Srivastava and J.S. Tandon. 1993. Immunostimulant agents from Andrographis paniculata. J Nat Prod. 56(7):995-999.

50. Rahman, M. D. 2004. Efficiency of V4 HR Newcastle disease (V4HR-ND) vaccine in Broiler Birds in Bangladesh. J. Poult. Sci. ,2004, 5,365-368.

51. Rehman, H., S. Abbas and N. lohahet. 2003. Laboratory Manual of Physiology, Vol. 1. Society of Veterinary Physiology, Lahore, Pakistan.

52. Sharif, S. 2007. Probiotics Help Produce Safer, Healthier Chickens. University of Guelph Ontario Veterinary College. College News Published January 19. 2007; 338 Views.

53. Sharma, J. M., I. J. Kim, S. Rautenschlein and H.Y. Yeh. 2000. Infectious bursal disease virus of chickens: pathogenesis and immunosuppression. Dev Comp Immunol. 2000;24:223-235.

54. Shivachandra, S.B., R.L. Sah, S.D. Singh, J.M. Kataria and K. Manimaran. 2003. Immunosuppression in broiler chicks fed aflatoxin and inoculated with fowl adenovirus serotype-4 (FAV-4) associated with hydropericardium syndrome. Vet Res Com. 2003;27:39-51.

55. Silverstein, A.M. 2001. The lymphocyte in immunology: from James B. Murphy to James L. Gowans. Nat. Immunol. 2, 569-571.

56. Spradbrow, P.B. 1995. Policy framework for smallholder rural poultry development, Sustainable rural poultry production in Africa, Proceedings of an international workshop held at the International Livestock Research Institute, 13-16 June 1995, Addis Ababa, Ethiopia. pp. 66-74.

57. SPSS. 1997. SPSS user's guide statistics Version 10. Copyright SPSS Inc., USA.

58. Sugiarto, H. and P.L. Yu, 2004. Avian antimicrobial peptides: the defense role of beta-defensins. Biochem. Biophys. Res. Commun. 323, 721-727.

59. Tadelle, D.and Y. Jobre. 2004. A review of the importance and control of Newcastle disease in Ethiopia. Ethiop. Vet. J. 1: 71-81.

60. Tollba, A. A. H and R. M. Mahmoud. 2009. How to Control the Broiler Pathogenetic Intestinal Flora Under Normal or Heat Stress Conditions: 1. Medicinal Plants, Probiotics- Sand as Litter, Egypt. Poult. Sci. Vol (29) (II): (565-587)

61. Zeleki, A., T. Sori, E. Gelaye and G. Azelet. 2005. Newcastle disease in village chickens in Southern and Rift Valley District in Ethiopia. J. Poult. Sci. ,2005,4(7), 507-510.

62. Zhang, X., X. Zhang and Q. Yang. 2007. Effect of compound mucosal immune adjuvant on mucosal and systemic immune responses in chicken orally vaccinated with attenuated Newcastle-disease. Vaccine. 2007;25:3254-3262.

63. Zhao, C., T. Nguyen, L. Liu, R. E. Sacco, K. A. Brogden, and R.I. Lehrer, 2001. Gallinacin-3, an inducible epithelial beta-defensin in the chicken. Infect. Immun. 69, 2684-2691. 